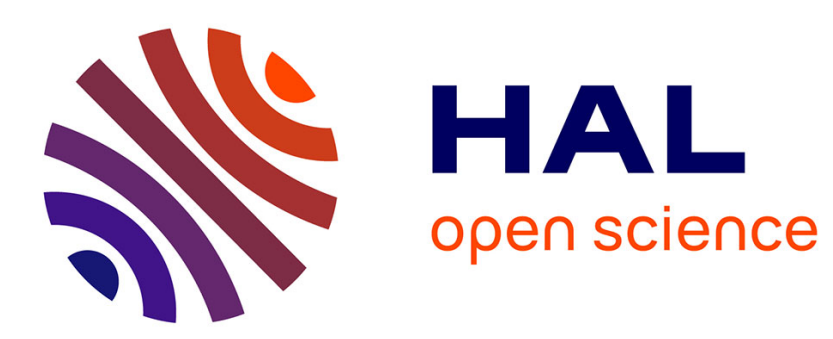

\title{
Effect of layers relative moisture content on the IB strength of pine tannin bonded particleboard
}

\author{
M. Sedano-Mendoza, P. Navarrete, A. Pizzi
}

\section{To cite this version:}

M. Sedano-Mendoza, P. Navarrete, A. Pizzi. Effect of layers relative moisture content on the IB strength of pine tannin bonded particleboard. European Journal of Wood and Wood Products, 2010, 68 (3), pp.355-357. 10.1007/s00107-010-0452-8 . hal-00600771

\section{HAL Id: hal-00600771 \\ https://hal.science/hal-00600771}

Submitted on 16 Jun 2011

HAL is a multi-disciplinary open access archive for the deposit and dissemination of scientific research documents, whether they are published or not. The documents may come from teaching and research institutions in France or abroad, or from public or private research centers.
L'archive ouverte pluridisciplinaire HAL, est destinée au dépôt et à la diffusion de documents scientifiques de niveau recherche, publiés ou non, émanant des établissements d'enseignement et de recherche français ou étrangers, des laboratoires publics ou privés. 


\title{
EFFECT OF LAYERS RELATIVE MOISTURE CONTENT ON THE IB STRENGTH OF PINE TANNIN BONDED PARTICLEBOARD
}

\author{
M. Sedano-Mendoza, P.Navarrete, A.Pizzi
}

This article is dedicated to Gerd Wegener on the occasion of his retirement as professor at the Technische Universität München.

\begin{abstract}
Relative percentage of moisture content of surface and core layers in pine tannin-bonded particleboard influences markedly the internal bond (IB) strength of the board. This is due to the differential compression exercised on the layers related to their moisture content. The moisture content differential between surface and core layers in particleboard during pressing is a determining parameter for the internal bond (IB) strength of particleboard. In the case of tannin adhesives where these differences can be more pronounced than for synthetic adhesive the effect is more easily observable.
\end{abstract}

\section{INTRODUCTION}

Pressing conditions of particleboard and other panel products are as much responsible for the good IB strength results as the performance of the binder itself. In this regard the density profile along the thickness of the panel is one of the most determining factors. The density profile along the thickness of the panel can be changed according to different techniques and manipulates different parameters, with large effects on the IB strength of the panel. The higher the moisture content of one layer the higher the internal bond (IB) strength of the panel. For tannin-bonded panels, such as OSB, press closing time, mat permeability and strength development during densification have already been found to be determining parameters for board performance (Pichelin et al. 2001). The press temperature will also influence the steam front transfer time to the core layer (Pichelin et al. 2001). However, the relative moisture content percentage of surfaces and core of the furnish before panel pressing is perhaps the parameter the manipulation of which causes a more marked effect. While this is known in particleboard and other wood panels manufacture the same applies, but even to a more extreme extent, to tannin-bonded particleboard. This is the case as such adhesives allow the use, both in the laboratory and in the factory, of much higher moisture content percentages. Thus, the difference in results observed by manipulating the relative moisture content percentage before pressing of the board surfaces and core in tannin-bonded boards is particularly telling. In this paper, this effect is investigated for pine tannin-bonded particleboard.

\section{MATERIALS AND METHODS}

Triplicate one layer laboratory particleboards of $350 \times 300 \times 14 \mathrm{~mm}^{3}$ dimension were prepared using a mixture of core particles of beech (Fagus sylvatica) and Norway spruce (Picea abies) wood particles at $28 \mathrm{~kg} / \mathrm{cm}^{2}$ maximum pressure and $190-195^{\circ} \mathrm{C}$ press temperature. The resin used was composed of a $40 \%$ solution of pine (Pinus radiata) tannin extract in water, at $\mathrm{pH} 5$, to which $5 \%$ by weight on tannin content of paraformaldehyde powder was added. The resin solids load on dry wood was maintained at $10 \%$ of pine tannin extract solids. The moisture content was varied in core and surfaces according to what is indicated in Table 1. The total pressing time was maintained at 7.5 minutes. All particleboards were tested for dry internal bond (IB) strength according to EN 312 (EN 312 1995). The IB strength test was done on five board specimens and is a tension test perpendicular to the plane of the board. Thus, each IB strength and panel density result in the tables is the average of 15 specimens. The panel density reported in the tables is the average of the density of the series of specimens for each series of panels.

The panel density profiles were done on all the specimens tested for internal bond, before destructive testing, by using a Grecon Da-X (Greten, Germany) density profiler.

M. Sedano-Mendoza, P.Navarrete, A.Pizzi ( $\square$ )

ENSTIB-LERMAB, University of Nancy 1, 27 rue du Merle Blanc, BP 1041, 88051 Epinal cedex 9, France. e-mail: antonio.pizzi@enstib.uhp-nancy.fr 


\section{RESULTS AND DISCUSSION}

The results of the series of one layer particleboard reported in Table 1 indicate clearly the action of moisture content on a tannin adhesive. As tannins contrary to phenol do not melt, they need water to be mobile, thus a good IB result depends on the amount of moisture content percentage present in the board at the moment of pressing. This is valid for most types of panels and has been clearly demonstrated for OSB panels (Pichelin et al. 2001). In general, in industrial panels it is a compromise between improving the mobility of the tannin during pressing and to limit the excess of water to avoid vapour blisters in the panel. The latter is generally not a problem in laboratory particleboard, where elimination of excess vapour is greatly facilitated by the more convenient board edge perimeter to board volume ratio. This is true for one layer boards in Table 1. The higher the moisture content of the one layer the higher the internal bond (IB) strength of the panel as already shown for OSB (Pichelin et al. 2001). For tannin-bonded panels, such as OSB, press closing time, mat permeability and strength development during densification have also been found to be determining parameters for board performance (Pichelin et al. 2001). The press temperature will also influence the steam front transfer time to the core layer (Pichelin et al. 2001).

Passing to three layer boards and playing on the differential in percentage moisture content between board surfaces and core confirms that the relative compression ratio of surfaces and core is also a determining parameter for IB strength. As compression depends on the moisture content of the layer, be it surface or core, the wetter the more compressible it is, while the drier the less compressible it is, hence the less densifiable is the layer. Thus, a board in which the moisture content of the surfaces is much higher than that of the core, presents surfaces compressed to much higher density. In Fig 1, an example of one of these board density profiles is given as a function of board thickness indicating the high densification of the moister surfaces in relation to the core, core at a density minimum of 580 $\mathrm{kg} / \mathrm{m}^{3}$. The IB strength is correlated with the lower density through the panel thickness. The board at moisture content percentage of $25 \%$ surface $/ 15 \%$ core has then a lower IB strength than both those at $15 \% / 15 \%$ moisture content and 10\% / 15\% moisture content (Table 1). In Fig. 2, an example of the density profile of a $10 \% / 15 \%$ board is given in which the moister core has had a greater chance to densify in relation to the drier surfaces, with a consequent increase of the minimum board density to $628 \mathrm{~kg} / \mathrm{m}^{3}$ in the core with a higher corresponding IB strength (Table 1) and a lower densification of the surfaces (Fig. 2). In conclusion, relative compression ratio of surface and core layers can be added as another determining parameter for the IB strength of a tannin-bonded particleboard.

\section{REFERENCES}

EN 312 (1995) Wood particleboard - specifications

Pichelin F, Pizzi A, Frühwald A, Triboulot P (2001) Exterior OSB preparation technology at high moisture content - Part 1: Transfer mechanisms and pressing parameters, Holz Roh Werkst 59(4): $256-265$ 
Table 1. Internal bond (IB) strength results for one layer and three layer particleboards at different moisture contents at the moment of pressing

Tabelle 1 Querzugfestigkeit einschichtiger und dreischichtiger Spanplattem in Abhängigkeit der Holzfeuchte beim Pressen

\begin{tabular}{ccc}
\hline $\begin{array}{c}\text { Moisture content } \\
\begin{array}{c}\text { Surface/core/surface } \\
(\%)\end{array}\end{array}$ & $\begin{array}{c}\text { Ave. board density } \\
\left(\mathrm{kg} / \mathrm{m}^{3}\right)\end{array}$ & $\begin{array}{c}\text { Dry IB strength } \\
\text { (MPa) }\end{array}$ \\
\hline$\underline{\text { One layer boards }}$ & & \\
\hline 15 & 704 & $0.53 \pm 0.05$ \\
13 & 700 & $0.50 \pm 0.05$ \\
10 & 717 & $0.41 \pm 0.05$ \\
9 & 706 & $0.39 \pm 0.05$ \\
& & \\
\hline Three layer boards & 702 & $0.36 \pm 0.06$ \\
$25-15-25$ & 704 & $0.53 \pm 0.05$ \\
$15-15-15$ & 704 & $0.55 \pm 0.05$ \\
$10-15-10$ & & \\
\hline
\end{tabular}




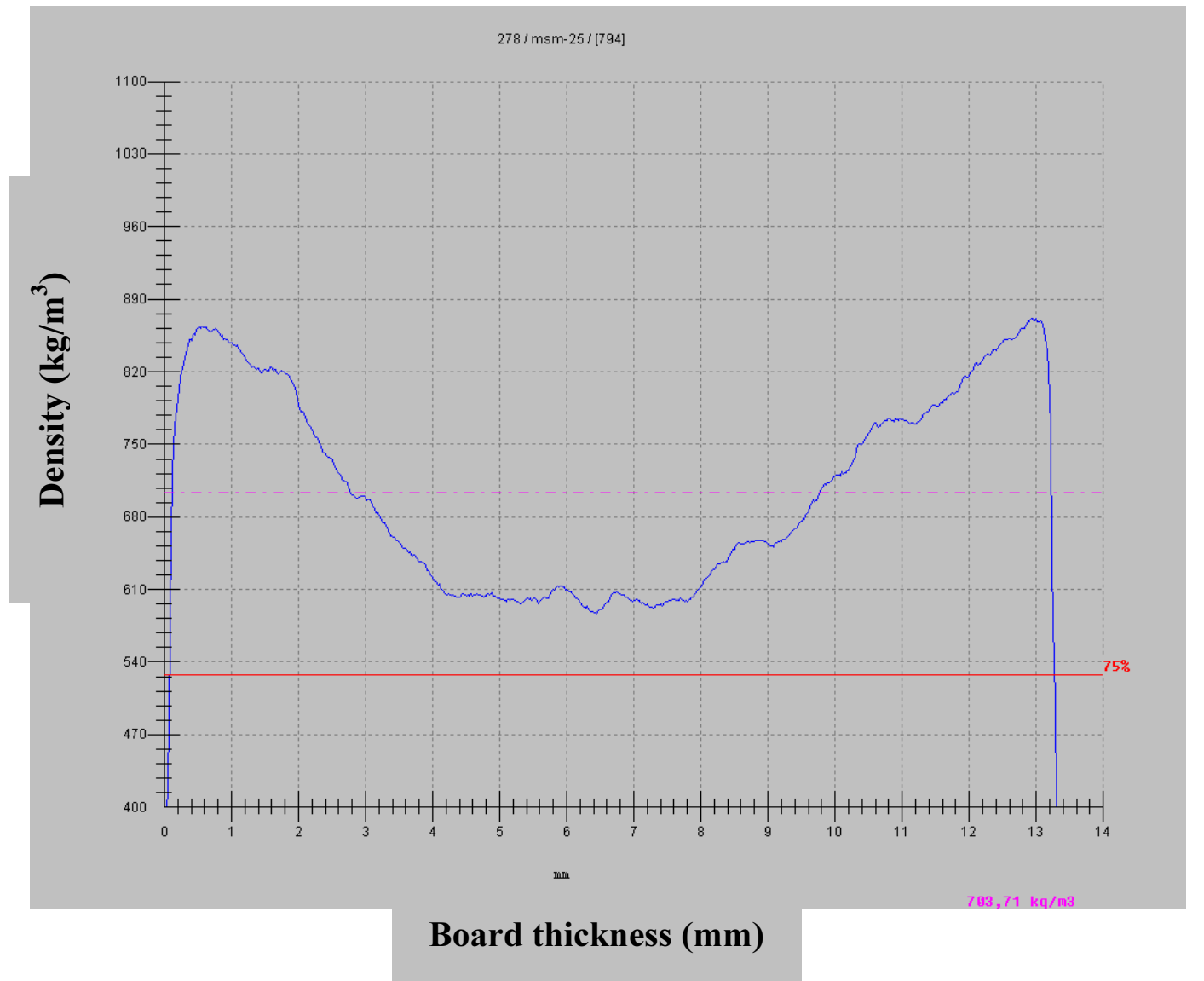

Fig. 1. Density profile of a three layer particleboard bonded with a pine tannin adhesive and presenting surfaces/ core moisture contents at the moment of pressing of $25 \%$ and $15 \%$, respectively.

Abb. 1 Dichteprofil einer dreischichtigen, mit Kieferntanninklebstoff verklebten Spanplatte mit einer Holzfeuchte beim Pressen von 25\% in den Deckschichten und 15\% in der Mittelschicht. 


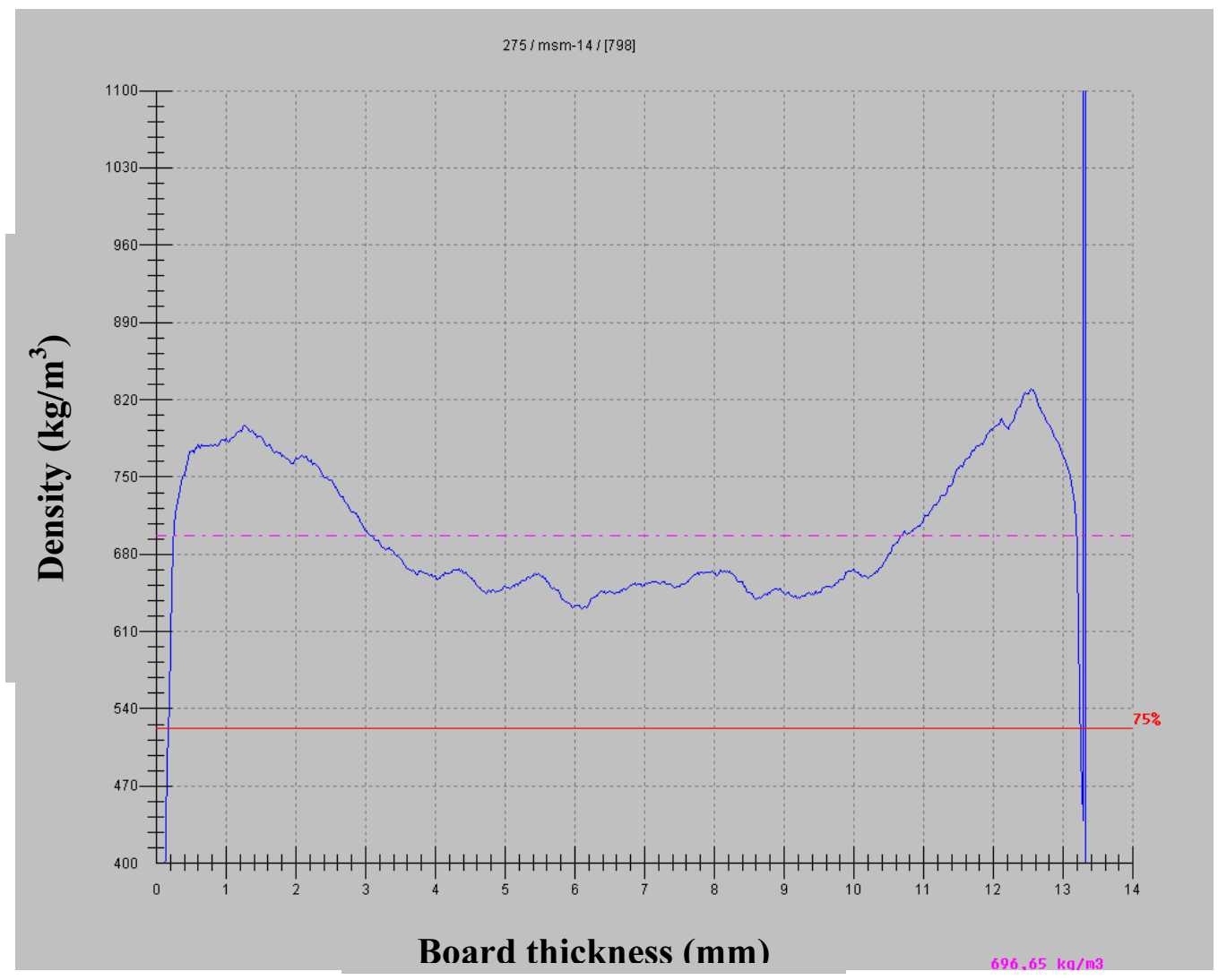

Fig. 2. Density profile of a three layer particleboard bonded with a pine tannin adhesive and presenting surfaces/ core moisture contents at the moment of pressing of $10 \% / 15 \%$, respectively.

Abb. 2 Dichteprofil einer dreischichtigen, mit Kieferntanninklebstoff verklebten Spanplatte mit einer Holzfeuchte beim Pressen von 10\% in den Deckschichten und 15\% in der Mittelschicht. 